ARTIKEL PENELITIAN

\title{
ANALISIS REGRESI LOGISTIK UNTUK FAKTOR-FAKTOR YANG MEMPENGARUHI STATUS GIZI REMAJA
}

\author{
Riska Habriel Ruslie, Darmadi \\ Dokter RSUD Z.A. Pagar Alam Way Kanan, Lampung \\ email : ypds_88@yahoo.co.id
}

\begin{abstract}
Abstrak
Sebagian besar penelitian tentang gizi lebih memperhatikan masalah ketidakseimbangan antara asupan makan dan aktivitas fisik dan kurang memperhatikan faktor-faktor lainnya seperti body image, depresi, dan gender secara terintegrasi. Penelitian ini bertujuan mengetahui prevalensi status gizi remaja dan hubungannya dengan pelbagai aspek seperti nutrisi, aktivitas fisik, body image, depresi, dan gender. Dilakukan penelitian cross-sectional terhadap mahasiswa Fakultas Kedokteran Atma Jaya Jakarta. Melalui perhitungan besar sampel dipilih 147 mahasiswa secara Simple Random Sampling. Terdapat 3 responden yang dikeluarkan sebab menderita penyakit kronik. Terhadap responden dilakukan wawancara mengenai asupan makan, aktivitas fisik, body image, dan depresi menggunakan kuesioner yang sudah diuji coba. Dengan Program SPSS versi 16 dilakukan analisis univariat, bivariat, dan multivariat. Didapatkan prevalensi underweight $9,03 \%$, status gizi normal $70,83 \%$, dan overweight 20,14\%. Hasil studi menunjukkan asupan makan yang berlebih, aktivitas fisik kurang, body image positif, dan mahasiswa laki-laki berhubungan secara signifikan dengan overweight (p-value $<0,05$ ).
\end{abstract}

Kata kunci : Status Gizi, Body Image, Depresi, Remaja

\section{Abstract}

Most studies in nutrition gave more concern in the imbalance between food intake and physical activity, however less concern was given to other factors such as body image, depression, and gender. The purpose of this research is to know about adolescents' nutritional status prevalence and its relation with other aspects such as food intake, physical activity, body image, depression, and gender. This study was done using cross sectional method. Population of this study was the students of the Faculty of Medicine of Atma Jaya Catholic University. 147 were chosen randomly with Simple Random Sampling. Three respondents were excluded because they had chronic illness. The respondents were questioned about food intake, physical activity, body image, and depression using validated questionnaires. Univariate, bivariate, multivariate analyses were done by SPSS version 16. The result shows the prevalence of underweight 9,03\%, normal nutritional status $70,83 \%$, and overweight $20,14 \%$. Higher food intake, less physical activity, positive body image, and male are related significantly with overweight (p-value $<0,05$ ).

Key word : Nutritional Status, Body Image, Depression, Adolescent 


\section{PENDAHULUAN}

Prevalensi obesitas makin lama makin meningkat, hampir setengah milyar penduduk dunia saat ini tergolong overweight atau obese ${ }^{(1)}$ Data hasil survei nasional Behavioral Risk Factor Surveillance System di Amerika menunjukkan prevalensi obesitas pada remaja meningkat dari $12 \%$ pada tahun 1991 menjadi $17,9 \%$ pada tahun 1998. ${ }^{(2)}$ Di DKI Jakarta, prevalensi obesitas meningkat dengan bertambahnya umur. Pada anak umur 6-12 tahun ditemukan obesitas sekitar 4\%, pada remaja 12-18 tahun ditemukan $6,2 \%$, dan pada umur $17-18$ tahun $11,4 \% .{ }^{(3)}$

Obesitas (WHO) adalah suatu kondisi terjadi akumulasi lemak yang banyak dalam tubuh. ${ }^{(4)}$ Menurut Dietz, ada 4 periode kritis terjadinya obesitas, yaitu masa prenatal, masa bayi, masa adiposity rebound, dan masa remaja. Obesitas yang terjadi pada masa remaja, $30 \%$ akan melanjut sampai dewasa menjadi obesitas persisten. ${ }^{(5)}$

Obesitas yang terjadi pada masa remaja ini perlu mendapatkan perhatian sebab obesitas yang timbul pada waktu anak dan remaja bila kemudian berlanjut hingga dewasa akan sulit diatasi secara konvensional (diet dan olahraga). Selain itu, obesitas pada remaja tidak hanya menjadi masalah bagi kesehatan di kemudian hari (kardiovaskular, diabetes mellitus dan lain-lain), tetapi juga membawa masalah bagi kehidupan sosial dan emosi yang cukup berarti pada remaja. ${ }^{(6)}$

Sebagian besar penelitian tentang gizi lebih memperhatikan masalah ketidak-seimbangan antara asupan makan dan aktivitas fisik dan kurang memperhatikan faktor-faktor lainnya secara terintegrasi seperti aspek psikologis (body image), aspek psikiatrik (depresi), dan aspek gender. Berdasarkan alasan-alasan di atas, mendorong diadakan penelitian ini yang bertujuan untuk mengetahui prevalensi status gizi pada kelompok remaja dan hubungannya dengan pelbagai aspek seperti nutrisi, aktivitas fisik, body image, depresi, dan gender.

\section{BAHAN DAN METODA}

Penelitian ini merupakan studi cross-sectional yang dilakukan pada tahun 2010. Penelitian dilakukan terhadap mahasiswa Fakultas Kedokteran Unika Atma Jaya (FK UAJ). Dipilih 147 mahasiswa secara Simple Random Sampling. Terdapat 3 responden yang dikeluarkan sebab menderita penyakit kronik. Terhadap responden dilakukan wawancara mengenai asupan makan, aktivitas fisik, body image, dan depresi. Asupan makan menggunakan Food Frequency Questionnaire yang jenis makanannya sudah disesuaikan untuk masyarakat Indonesia dan telah diuji coba. Hasil ukur untuk asupan makan adalah asupan kurang dan cukup.

Aktivitas fisik dinilai menggunakan kuesioner Riset Kesehatan Dasar 2007, Departemen Kesehatan Republik Indonesia. Hasil ukur untuk aktivitas fisik adalah aktivitas fisik kurang dan cukup. Kegiatan aktivitas fisik dikategorikan 'cukup' apabila kegiatan dilakukan terus-menerus sekurangnya 10 menit dalam satu kegiatan tanpa henti dan secara kumulatif 150 menit selama lima hari dalam satu minggu. Selain frekuensi dilakukan pula pengumpulan data intensitas, yaitu jumlah hari melakukan aktivitas berat, sedang, dan berjalan. Perhitungan jumlah menit aktivitas fisik dalam seminggu mempertimbangkan pula jenis aktivitas yang dilakukan, di mana aktivitas diberi pembobotan, masing-masing untuk aktivitas 'berat' empat kali, aktivitas 'sedang' dua kali terhadap aktivitas 'ringan' atau jalan santai. 
Body image dinilai menggunakan kuesioner dari Drexel Student Counceling Center. Hasil ukur untuk body image adalah body image negatif dan positif. Dikatakan memiliki body image negatif bila menjawab minimal 3 jawaban "ya" dari 9 pertanyaan.

Depresi dinilai menggunakan Self Reporting Questionnaire-20 WHO. Dikatakan mengalami depresi bila menjawab minimal 6 jawaban "ya" (SRQ-20 terdiri dari 20 butir pertanyaan yang mempunyai pilihan jawaban "ya" dan "tidak"). Nilai 6 sebagai nilai batas pisah sesuai penelitian uji validitas yang pernah dilakukan oleh Hartono dari Badan Litbangkes pada tahun 1995.

Selain itu dilakukan pengukuran tinggi badan dan berat badan untuk menentukan status gizi. Pengukuran tinggi badan menggunakan alat Mikrotoise. Pengukuran berat badan dengan menggunakan timbangan injak geser. Status gizi dihitung berdasarkan berat badan dan tinggi badan dengan rumus sebagai berikut : $\mathrm{BB}(\mathrm{kg}) / \mathrm{TB}^{2}\left(\mathrm{~m}^{2}\right)$. Batasan BMI untuk menilai status gizi penduduk umur 15 tahun ke atas adalah underweight bila $\mathrm{BMI}<18,5$; normal bila $\mathrm{BMI}>=18,5-<24,9$; overweight bila BMI $>=25,0-<27,0$; dan obese bila BMI $>=27,0$.

Data diolah dengan SPSS versi 16 dan dianalisis secara univariat, bivariat (menggunakan uji Chi Square), dan uji regresi logistik ganda. Besarnya penyimpangan yang diinginkan $(\alpha)$ adalah 0,05 .

\section{HASIL PENELITIAN \\ Karakteristik Responden}

Dari 144 responden, terdiri dari 54 laki-laki $(37,5 \%)$ dan 90 perempuan $(62,5 \%)$, yang mempunyai usia rata-rata 19,84 tahun. Sebanyak 45 orang tinggal sendiri (tinggal di kos/ apartemen sendiri - 31,25\%) dan 99 orang tinggal bersama keluarga $(68,75 \%)$.

\section{Status Gizi}

Mahasiswa FK UAJ mayoritas memiliki status gizi normal $(70,83 \%)$, diikuti dengan overweight $(20,14 \%)$, dan underweight $(9,03 \%)$. Mahasiswa FK UAJ memiliki prevalensi overweight yang lebih besar dibandingkan dengan remaja SMAN 3 di Semarang maupun remaja di Jakarta, di mana prevalensi overweight di SMAN 3 Semarang sebesar 9,03\%, remaja Jakarta berusia 12-18 tahun sebesar 6,2\%, dan remaja Jakarta berusia 17-18 tahun sebesar $11,4 \%$. $^{3,7}$ Hal ini mungkin disebabkan karena perbedaan yang mencolok pada asupan makan antara mahasiswa FK UAJ dengan SMAN 3 Semarang maupun remaja di Jakarta. Hasilnya adalah sebagaimana terlihat pada Tabel 1. 
Tabel 1. Asupan Makan, Aktivitas Fisik, Body Image, Depresi, dan Status Gizi Responden

\begin{tabular}{llcc}
\hline \multicolumn{1}{c}{ Variabel } & Kategori & \multicolumn{2}{c}{ Total } \\
\hline Asupan Makan & & Jumlah & $(\%)$ \\
& Kurang & 40 & $(27.78)$ \\
Aktivitas Fisik & Cukup & 104 & $(72.22)$ \\
& Cukup & 57 & $(39.58)$ \\
Body image & Kurang & 87 & $(60.42)$ \\
& Negatif & & \\
Depresi & Positif & 77 & $(53.47)$ \\
& Ya & 67 & $(46.53)$ \\
Status Gizi & Tidak & 44 & $(30.56)$ \\
& & 100 & $(69.44)$ \\
& Kurus & & \\
& Normal & 13 & $(9.03)$ \\
& Gemuk & 102 & $(70.83)$ \\
& & 29 & $(20.14)$ \\
\hline
\end{tabular}

\section{Asupan Makan}

Mayoritas responden memiliki asupan makan yang cukup (72,22\%). Hanya 40 responden $(27,78 \%)$ yang memiliki asupan makan kurang. Keadaan ini mungkin disebabkan oleh tingginya status sosial ekonomi di kalangan mahasiswa yang berdampak pada pemenuhan asupan makan yang baik. Hasilnya adalah sebagaimana terlihat pada Tabel 1.

\section{Aktivitas Fisik}

Mayoritas responden memiliki aktivitas fisik yang kurang $(60,42 \%)$, sedangkan sisanya $(39,58 \%)$ memiliki aktivitas fisik cukup. Sementara itu, jumlah remaja (15-24 tahun) yang kurang beraktivitas menurut Riskesdas 2007 sebesar 52\%. ${ }^{(8)}$ Lebih tingginya prevalensi aktivitas fisik kurang mahasiswa FK UAJ dibandingkan dengan remaja Indonesia mungkin karena mahasiswa FK UAJ terlalu sibuk dengan jadwal kuliah sehingga waktu yang bisa digunakan untuk berolahraga sangat terbatas. Hasilnya adalah sebagaimana terlihat pada Tabel 1 .
Tingginya aktivitas fisik kurang baik pada mahasiswa FK UAJ, maupun remaja di Indonesia (Riskesdas 2007) mungkin disebabkan oleh kemajuan teknologi karena pengaruh globalisasi yang membuat anak muda sekarang semakin tidak pernah beraktivitas, misalnya lebih menghabiskan waktunya untuk bermain komputer, menonton televisi, dan memilih bepergian dengan kendaraan bermotor.

\section{Body Image}

Responden penelitian ini lebih banyak memiliki body image negatif yaitu sebanyak 77 mahasiswa $(53,47 \%)$, sedangkan sebanyak 67 mahasiswa $(46,53 \%)$ memiliki body image positif. Persentase body image negatif di mahasiswa FK UAJ ini sedikit lebih rendah bila dibandingkan dengan hasil penelitian body image terhadap remaja SMA di Jakarta Selatan di mana prevalensi body image negatif remaja SMA di Jakarta Selatan sebesar $57,41 \% .^{(9)}$ Hasilnya adalah sebagaimana terlihat pada Tabel 1 . 
Hasil studi ini wajar karena res- negatif. Ternyata hal ini sesuai dengan ponden lebih banyak berjenis kelamin hasil tabulasi silang antara gender perempuan. Remaja perempuan cen- dengan body image, di mana remaja derung lebih memperhatikan bentuk perempuan cenderung memiliki body tubuhnya dibandingkan dengan kaum image negatif. Hasilnya adalah lelaki sehingga kaum perempuan sebagaimana terlihat pada Tabel 2. cenderung memiliki citra diri yang

Tabel 2. Hubungan Gender dengan Body Image

\begin{tabular}{llll}
\hline $\begin{array}{l}\text { Variabel } \\
\text { p-value }\end{array}$ & B.Image Negatif & B.Image Positif & Total Value df
\end{tabular}

\begin{tabular}{ccccccccc}
\hline & $\mathbf{N}$ & $(\boldsymbol{\%})$ & $\mathbf{N}$ & $(\boldsymbol{\%})$ & $\mathbf{N}$ & $\mathbf{\%}$ & & \\
\hline Gender Laki & 20 & 37.04 & 34 & 62.96 & 54 & 100 & 9.380 & 1 \\
$\begin{array}{c}\text { 0.002* } \\
\text { Perempuan }\end{array}$ & 57 & 63.33 & 33 & 36.67 & 90 & 100 & & \\
\hline
\end{tabular}

$*$ p-value $<0.05$

\section{Depresi}

Sebanyak 44 responden $(30,56 \%)$ mengalami depresi, sedangkan sebanyak 100 responden $(69,44 \%)$ tidak mengalami depresi. Walaupun mayoritas responden tidak mengalami depresi, jumlah mahasiswa FK UAJ yang mengalami depresi ini 3,51 kali lebih besar dibandingkan dengan tingkat depresi remaja usia 1524 tahun di Indonesia hasil Riskesdas Litbangkes 2007 (yang menggunakan SRQ-20 juga), di mana prevalensi remaja yang mengalami stres hanya sebesar $8,7 \% .^{(8)}$ Hal ini mungkin disebabkan oleh tingginya stresor selama kuliah di fakultas kedokteran. Hasilnya adalah sebagaimana terlihat pada Tabel 1.

Faktor-Faktor yang Berhubungan dengan Status Gizi

Asupan Makan

Terdapat hubungan yang bermakna secara positif antara asupan makan dengan status gizi mahasiswa ( $p$ value 0,015 ), yang berarti makin tinggi asupan makan makin overweight. Hasilnya adalah sebagaimana terlihat pada Tabel 3. 
Tabel 3. Hubungan Antara Asupan Makan, Aktivitas Fisik, Body Image, Depresi, Gender dengan Status Gizi

\begin{tabular}{|c|c|c|c|c|c|c|c|}
\hline \multicolumn{2}{|c|}{$\begin{array}{l}\text { Variabel } \\
\text { p-value }\end{array}$} & & \multirow{2}{*}{$\begin{array}{l}\text { Kurus } \\
\text { Jumlah(\%) } \\
\end{array}$} & \multirow{2}{*}{$\begin{array}{l}\text { Normal } \\
\text { Jumlah (\%) } \\
\end{array}$} & \multirow{2}{*}{$\begin{array}{l}\text { Gemuk } \\
\text { Jumlah (\%) }\end{array}$} & \multirow[t]{2}{*}{ Value } & \multirow[t]{2}{*}{ df } \\
\hline & & & & & & & \\
\hline Asupan & $\begin{array}{l}\text { Kurang } \\
0.015^{*}\end{array}$ & & $8(20)$ & $26(65)$ & $6 \quad(15)$ & 8.378 & 2 \\
\hline Makan & Cukup & & $5(4.81)$ & $76(73.08)$ & $23(22.11)$ & & \\
\hline Aktivitas & $\begin{array}{l}\text { Cukup } \\
0.027^{*}\end{array}$ & & $8(14.03)$ & $43(75.44)$ & $6(10.53)$ & 7.231 & 2 \\
\hline Fisik & Kurang & & $5(5.75)$ & $59(67.82)$ & $23(26.43)$ & & \\
\hline Body & $\begin{array}{l}\text { Negatif } \\
0.007 *\end{array}$ & & 8 (10.39) & $61(79.22)$ & $8 \quad(10.39)$ & 9.794 & 2 \\
\hline Image & Positif & & $5(7.46)$ & $41(61.19)$ & $21(31.34)$ & & \\
\hline \multirow[t]{2}{*}{ Depresi } & $\begin{array}{l}\text { Ya } \\
0.114\end{array}$ & & $7(15.91)$ & $27(61.36)$ & $10(22.73)$ & 4.336 & 2 \\
\hline & Tidak & & $6(6)$ & $75(75)$ & $19(19)$ & & \\
\hline \multirow[t]{2}{*}{ Gender } & Laki & & \multicolumn{2}{|c|}{ Underweight + Normal $=38(70.37)$} & $16(29.63)$ & 4.839 & 1 \\
\hline & $0.028^{*}$ & Perempuar & an $\quad$ Un & ight + Normal $=7$ & (85.56) $\quad 13$ & & \\
\hline
\end{tabular}

Pengaruh aspek nutrisi terhadap kejadian obesitas ini juga dilaporkan oleh Gregorius dalam studi case control terhadap remaja SMA yang obesitas di Semarang maupun dengan hasil studi cross-sectional yang dilakukan oleh Ebbeling CB terhadap remaja di Boston, di mana dalam penelitianpenelitian tersebut juga didapatkan adanya hubungan yang bermakna secara positif antara asupan makan dengan status gizi. ${ }^{(7,10)}$

\section{Aktivitas Fisik}

Terdapat hubungan yang bermakna secara negatif antara aktivitas fisik dengan status gizi mahasiswa ( $\mathrm{p}$ value 0,027 ), di mana semakin rendah aktivitas fisik, semakin overweight. Hasilnya adalah sebagaimana terlihat pada Tabel 3.

Pengaruh aktivitas fisik terhadap status gizi ini juga dilaporkan oleh Gregorius dalam penelitian terhadap remaja SMA yang obesitas di Semarang maupun studi yang dilakukan oleh Kimm terhadap remaja, di mana diperoleh kesimpulan terdapat hubungan yang bermakna secara negatif antara aktivitas fisik dengan status gizi remaja. ${ }^{(7,11)}$

\section{Body Image}

Terdapat hubungan yang bermakna secara positif antara body image dengan status gizi mahasiswa ( $\mathrm{p}$ value 0,007 ), di mana semakin positif body image seseorang makin overweight. Hasilnya adalah sebagaimana terlihat pada Tabel 3.

Pengaruh body image terhadap status gizi ini juga dilaporkan oleh Gregorius terhadap remaja SMA yang mengalami obesitas di Semarang, di mana diperoleh kesimpulan terdapat hubungan bermakna secara positif antara body image dengan status gizi remaja. ${ }^{(7)}$

\section{Depresi}

Dalam penelitian ini diperoleh kesimpulan tidak adanya hubungan yang bermakna antara depresi dengan status gizi mahasiswa ( $\mathrm{p}$-value : 0,114 ). 
Hal ini mungkin terjadi karena SRQ-20 kurang sensitif untuk menilai tingkat depresi dibandingkan instrumen psikiatri lainnya. Hasilnya adalah sebagaimana terlihat pada Tabel 3.

Pengaruh psikopatologi terhadap status gizi ini juga dilaporkan oleh Chandra dari Departemen Psikiatri FKUI (2007) melalui studi crosssectional untuk melihat hubungan antara psikopatologi dengan obesitas pada 54 remaja SMA di Jakarta Selatan. Penelitian tersebut menggunakan uji Chi Square menghasilkan p-value 0,58, yang berarti tidak ada hubungan antara tingkat depresi dengan obesitas (status gizi). ${ }^{(9)}$

Akan tetapi, pengaruh depresi terhadap status gizi ini justru berkebalikan dengan studi cross-sectional yang dilakukan Britz di klinik obesitas INSULA di Jerman terhadap 47 remaja yang obesitas (menggunakan Munich Composite International Diagnostic Interview (M-CIDI)) menyimpulkan bahwa terdapat hubungan antara depresi dengan obesitas. ${ }^{(12)}$

Adanya perbedaan antara hasil penelitian Britz dengan penelitian ini mungkin disebabkan oleh beberapa faktor. Yang pertama adalah perbedaan dalam hal tempat pengambilan sampel; pada penelitian Britz, sampel diperoleh dari klinik gizi. Mungkin subyek yang datang ke klinik gizi sudah menyadari bahwa obesitas yang mereka alami merupakan suatu penyakit atau kelainan yang perlu pengobatan sehingga mereka sudah mengalami gejala depresi. Sedangkan pada penelitian ini, sampel diambil dari mahasiswa yang mungkin belum menganggap obesitas sebagai suatu masalah. Kedua, perbedaan jumlah sampel. Pada penelitian Britz jumlah sampel adalah 47 remaja obesitas sedangkan pada penelitian ini jumlah sampel 144 remaja. Ketiga, terdapat perbedaan penggunaan instru- men. Penelitian Britz menggunakan MCIDI, sedangkan pada penelitian ini menggunakan Self Reporting Questionnaire-20.

\section{Gender}

Diperoleh kesimpulan adanya hubungan antara gender dengan status gizi (p-value 0,028), di mana mahasiswa laki-laki cenderung overweight. Hal ini didukung oleh studi-studi sebelumnya. Di Portugal, dari 1198 remaja berusia 15-22 tahun ada $13,7 \%$ remaja pria obes dan $5,3 \%$ remaka perempuan obes. Di Brazil, dari 1465 remaja yang berusia 16-19 tahun diperoleh remaja pria memiliki resiko obesitas 2,25 kali dibandingkan remaja perempuan. ${ }^{(13,14)}$ Hasilnya adalah sebagaimana terlihat pada Tabel 3 .

\section{PEMBAHASAN}

Penelitian ini dilakukan dengan tujuan untuk mengetahui prevalensi status gizi mahasiswa dan faktor-faktor apa saja yang mempengaruhi status gizi pada remaja, khususnya mahasiswa FK UAJ.

Berdasarkan data penelitian ini, mahasiswa FK UAJ memiliki status gizi normal yang relatif tinggi (70,83\%), diikuti gemuk $(20,14 \%)$, dan kurus $(9,03 \%)$. Hal ini wajar karena mungkin mahasiswa FK UAJ memiliki status sosial-ekonomi tinggi dan pengetahuan tentang gizi yang baik.

Berdasarkan hasil pengolahan dan analisis data yang telah dijelaskan pada bagian hasil, asupan makan, aktivitas fisik, body image, dan gender mempunyai hubungan dengan status gizi mahasiswa, sedangkan faktor depresi tidak mempunyai hubungan dengan status gizi mahasiswa.

Mahasiswa FK UAJ lebih banyak yang berjenis kelamin perempuan $(62,5 \%)$. Remaja perempuan cenderung lebih memperhatikan bentuk tubuhnya 
dibandingkan dengan kaum lelaki menghindari asupan makan yang sehingga kaum perempuan cenderung berlebihan dan takut mengkonsumsi memiliki body image negatif (lihat makanan tinggi kalori. Dengan alasan Tabel 2). Hal inilah yang mungkin tersebut, peneliti memperkirakan adamembuat lebih tingginya prevalensi nya hubungan antara asupan makan body image negatif daripada body dengan dengan body image mahasiswa. image positif pada mahasiswa FK UAJ. Ternyata, hal ini sesuai dengan hasil

Mahasiswa yang mempunyai body tabulasi silang antara body image image negatif akan merasa mempunyai dengan asupan makan (lihat Tabel 4), di berat badan yang tidak ideal sehingga mana mahasiswa yang memiliki body akan berusaha untuk menurunkan berat image negatif akan memiliki pemenubadannya sampai berat badan yang ideal han asupan makan yang rendah.

menurut mereka. Mereka akan berusaha

Tabel 4. Hubungan Antara Body Image dan Asupan Makan

\begin{tabular}{|c|c|c|c|c|c|c|c|c|}
\hline \multirow[t]{2}{*}{$\begin{array}{l}\text { Variabel } \\
\text { p-value }\end{array}$} & \multicolumn{3}{|c|}{$\begin{array}{c}\text { Asupan Makan } \\
\text { Kurang }\end{array}$} & \multicolumn{2}{|c|}{$\begin{array}{c}\text { Asupan Makan } \\
\text { Cukup }\end{array}$} & \multirow{2}{*}{$\begin{array}{l}\text { Total } \\
\%\end{array}$} & \multirow{2}{*}{\multicolumn{2}{|c|}{ Value df }} \\
\hline & $\mathbf{N}$ & $(\%)$ & $\mathbf{N}$ & $(\%)$ & $\mathbf{N}$ & & & \\
\hline $\begin{array}{c}\text { B.Image Negatif } \\
0.014 *\end{array}$ & 28 & 36.36 & 49 & 63.64 & 77 & 100 & 6.081 & 1 \\
\hline Positif & 12 & 17.91 & 55 & 82.09 & 67 & 100 & & \\
\hline
\end{tabular}

*p-value $<0,05$

Selain dengan membatasi yang diinginkannya. Akan tetapi, dalam asupan makan, mahasiswa yang penelitian ini didapatkan hasil bahwa memiliki body image negatif diyakini body image tidak berhubungan dengan akan berupaya untuk beraktivitas fisik aktivitas fisik (lihat Tabel 5). supaya mendapatkan berat badan ideal

Table 5. Hubungan Antara Body Image dan Aktivitas Fisik

\begin{tabular}{|c|c|c|c|c|c|c|c|c|}
\hline \multirow{3}{*}{$\begin{array}{l}\text { Variabel } \\
\text { p-value }\end{array}$} & & \multicolumn{2}{|c|}{ Aktivitas Fisik } & \multicolumn{2}{|c|}{ Aktivitas Fisik } & \multirow[t]{2}{*}{ Total } & \multirow{2}{*}{\multicolumn{2}{|c|}{ Value df }} \\
\hline & & Cukup & & Tidak & & & & \\
\hline & $\mathbf{N}$ & $(\%)$ & $\mathbf{N}$ & $(\%)$ & & $\mathbf{N}$ & $\%$ & \\
\hline $\begin{array}{c}\text { B.Image Negatif } \\
0.389\end{array}$ & 33 & 42.86 & 44 & 57.14 & 77 & 100 & 0.742 & 1 \\
\hline Positif & 24 & 35.82 & 43 & 64.18 & 67 & 100 & & \\
\hline
\end{tabular}

Banyak responden perempuan berat badannya, seperti puasa ketat dan yang memiliki body image negatif mengkonsumsi laksatif. ${ }^{(15,16)}$

berusaha untuk membatasi asupan Walaupun dalam penelitian ini makan tetapi tidak berusaha untuk depresi tidak berhubungan dengan melakukan aktivitas fisik yang cukup. status gizi, namun tingkat depresi pada Hal ini mungkin disebabkan karena mahasiswa FK UAJ sangat tinggi bila remaja perempuan lebih memilih cara dibandingkan dengan hasil penelitian yang tidak sehat dalam menurunkan lain. Depresi tersebut memiliki banyak 
dampak negatif seperti sulit untuk saat menghadapi suatu tantangan dapat berkonsentrasi, kemampuan mengingat membuat mahasiswa menjadi lebih bisa berkurang, dan akhirnya berpengaruh mentolerir stressor dan belum menjadi terhadap hasil akademis. ${ }^{(17)}$ Tingginya stres yang patologis. Oleh karena itu, depresi pada mahasiswa yang mungkin kelas manajemen stres perlu diadakan disebabkan oleh karena padatnya kuliah untuk memberikan bekal kepada para di fakultas kedokteran ini bisa dian- mahasiswa.

tisipasi dengan mengetahui karak- Untuk melihat secara simultan teristik diri sendiri dengan baik, variabel-variabel independen yang memahami cara belajar yang paling berpengaruh terhadap kejadian obesitas, efektif. Selain itu, dengan memberikan maka dilakukan analisis regresi logistik kiat-kiat tentang cara mengontrol stres ganda. Hasilnya terlihat pada Tabel 6.

Tabel 6. Uji Regresi Logistik Ganda Faktor yang Berpengaruh terhadap Status Gizi

\begin{tabular}{lccc}
\hline \multicolumn{1}{c}{ Variabel independent } & p-value & Odds ratio & $\begin{array}{c}\text { 95\% confidence } \\
\text { interval }\end{array}$ \\
\hline $\begin{array}{l}\text { Body Image } \\
\text { Negatif } \\
\text { Positif }\end{array}$ & 0.015 & 1 & \\
\hline $\begin{array}{l}\text { Asupan Makan } \\
\text { Kurang }\end{array}$ & 0.029 & 3,252 & $1.262-8,421$ \\
$\begin{array}{l}\text { Cukup+berlebih } \\
\text { Aktivitas Fisik }\end{array}$ & & 1 & \\
$\begin{array}{l}\text { Cukup+berlebih } \\
\text { Kurang }\end{array}$ & 0.036 & 3.114 & $1.131-8.132$ \\
\hline Jenis Kelamin & & 1 & \\
$\begin{array}{l}\text { Perempuan } \\
\text { Laki-laki }\end{array}$ & 0,176 & 2.764 & $1.075-7,954$ \\
\hline
\end{tabular}

Kesimpulan dari tabel di atas laki berisiko obes 1,890 kali adalah terdapat 3 faktor yang paling dibandingkan mahasiswa perempuan. berpengaruh terhadap kejadian obesitas, yaitu body image, asupan makan, aktivitas fisik. Mahasiswa yang memiliki body image positif memiliki resiko obesitas 3,252 kali dibandingkan mereka yang memiliki body image negatif. Mahasiswa yang memiliki asupan makan kurang, lebih rendah resikonya 3,114 kali dibandingkan mereka yang memiliki asupan makan cukup dan berlebih. Mahasiswa yang memiliki aktivitas kurang memiliki resiko obesitas 2,764 kali dibandingkan mereka yang memiliki aktivitas fisik cukup dan berlebih. Mahasiswa laki-

\section{Kesimpulan}

1. Berdasarkan IMT, prevalensi status gizi paling banyak adalah status gizi normal $(70,83 \%)$, diikuti overweight $(20,14 \%)$, dan underweight $(9,03 \%)$.

2. Faktor-faktor yang mempengaruhi status gizi remaja antara lain asupan makan, aktivitas fisik, body image, dan gender. Sedangkan faktor depresi tidak mempengaruhi status gizi remaja.

3. Orang yang memiliki asupan makan berlebih, aktivitas fisik kurang, body image positif dan jenis kelamin laki- 
laki cenderung mengalami overweight.

\section{Saran}

1. Bagi peneliti yang ingin melakukan penelitian sejenis, hendaknya dapat mengungkapkan pengaruh faktor risiko yang lain yang berhubungan dengan kejadian obesitas pada remaja, seperti faktor genetik dan kelainan hormonal.

2. Perlu penelitian lebih lanjut menggunakan instrumen psikiatri yang lebih sensitif untuk menilai tingkat depresi.

\section{KEPUSTAKAAN}

1. Rossner S. Obesity. The Disease of The Twenty-First Century. Internat. J. Obesity \& Related Metabolic Disorders 2002; 26(Suppl 4):S2-4.

2. Mokdad AH, Serdula MK, Dietz WH, Bowman BA, Marks JS, Koplan JP. The spread of the obesity epidemic in the United States, 1991-1998. JAMA 1999; 282:1519-22.

3. Nasar SS. Obesitas pada anak. Aspek klinis dan pencegahan. Dalam: Samsudin, Nasar SS, Sjarif DR, penyunting. Naskah lengkap PKB-IKA XXXV. Masalah gizi ganda dan tumbuh kembang anak. Jakarta: Bina Rupa Aksara; 1995. h. 68-81.

4. WHO. Obesity: Preventing and Managing the Global Epidemic. Report on a WHO Consultation on Obesity, Geneva, 3-5 June 1997.WHO/NUT/NCD/98.1. Geneva: WHO.
5. Dietz WH. Periods of risk in childhood for the development of adult obesity what do need to learn?

http://www.nutrition.org/cgi/con tent/full/127/9/1884S, [March 10 2006].

6. Sanjaya TS. Studi tentang berbagai karakteristik remaja yang mengalami obesitas di SMP Pangudi Luhur Domenico Savio. Karya Tulis Ilmiah Universitas Diponegoro 1995: 1-19.

7. Virgianto, Gregorius. Konsumsi Fast Food Sebagai Faktor Risiko Terjadinya Obesitas pada Remaja Usia 15-17 Tahun. Media Medika Mudia 2006;3:34.

8. Badan Penelitian dan Pengembangan Kesehatan, Departemen Kesehatan Republik Indonesia. Riset Kesehatan Dasar 2007. Jakarta : Depkes; 2008.

9. Chandra,S. Hubungan Antara Obesitas dengan Psikopatologi pada Siswa SMU di Jakarta Selatan. Cermin Dunia Kedokteran 2007;34:289-95.

10. Ebbeling, CB. Compensation for Energy Intake from Fast Food among Overweight and Lean Adolescents. $J A M A$ 2004;23:2828-33.

11. Kimm,SY. Relation between the changes in physical activity and body mass index during adolescence : a multicentre longitudinal study. The Lancet 2005;366:301-7. 
12. Britz B, Siegfried W. Rates of Psychiatric Disorder in Clinical Study Group of Adolescents with Extreme Obesity and in Obese Adolescents Ascertained via A Population Based Study. International Journal of Obesity 2000;24:1707-14.

13. Sousa, Pedro Miguel. BodyImage and Obesity in Adolescence: A Comparative Study of Social-Demographic, Psychological, and Behavioral Aspects. The Spanish Journal of Psychology 2008,11(2):551-63.

14. Menezes CF, Neutzling MB, Carrazedo JA. Risk Factors for Overweight and Obesity in Adolescents of A Brazilian University:A Case-Control
Study. Nutr Hosp.2009;24(1): 17-24.

15. Wu TY. Gender Differences in Health Risk Behaviors and Physical Activity among Middle School Students. The Journal of School Nursing 2006; 22(1):2531.

16. Lowry R, Galuska DA, Fulton JE, Wechsler H, Kann L, Collins JL. Physical Activity, Food Choice, and Weight Management Goals and Practices among U.S. College Students. American Journal of Preventive Medicine 2000; 18(1):18-27.

17. Mudjaddid, Shatri H. Ilmu Penyakit Dalam. Jakarta : Fakultas Kedokteran Universitas Indonesia; 2006. h. 896-8. 